\title{
THE DEVELOPMENT OF THE UNESCO WORLD HERITAGE AREA IN PÉCS
}

\author{
Renáta NÉMETH-SZIGETI ${ }^{1}$, Balázs KÓSA², Kinga Éva PACZOLAI ${ }^{3}$ \\ University of Pécs, Faculty of Engineering and Information Technology, Pécs, Hungary \\ ${ }^{1}$ Department of Engineering Studies, reni.szigeti@gmail.com \\ ${ }^{2}$ Department of Visual Studies, kosa.balazs@mik.pte.hu \\ ${ }^{3}$ Department of Architecture and Urban Planning, paczolaik@gmail.com
}

\begin{abstract}
The World Heritage of Pécs is the most valuable historical relic in the city. The conservation, presentation and continuous development is significant. The significant parts of the area are: the Cella Septichora, the Old Christian Mausoleum and the crypts in Apáca Street. Through the design process our prime task is the restoration and expansion of the former development in 2006. The study focuses on creating the Cella Septichora concept.
\end{abstract}

Keywords: crypt, early Christian, Pécs, World Heritage, UNESCO, Cella Septichora.

\section{The early Christian necropolis of Pécs}

The archaeological presentation site is in the north-west part of Pécs. The discovery of the first crypt can be dated back to the start of the XVIII. century. After this in the year 1782 the Péter Pál burial chamber was found, which is an important, valuable and presented element of the visitor centre The area was added to the World Heritage list by UNESCO in 2000. Since then both its economic and theoretical value have been impeccable. [1][2][3]

\subsection{The history of Cella Septichora}

In 2006 the most significant excavations were undertaken, led by Prof. Dr. Zoltán Bahman, which allowed our relics - previously hidden underground - to be seen by visitors [1]. At the birth of Cella Septichora Visitor Center, it was possible they let the light enter the underground burial sites through a glass slab built into today's surface level, to make people understand that they are not walking in the catacombs but among chapels that once existed above the ground. The entrance has a symbolic meaning as it is a huge and transparent concrete (glass-concrete) gate with a small stream flowing next to it, (referring to the Early Christian symbol, water). The corridor leads to the huge, seven-apse hall of Cella Septichora which is covered by an approximately $300 \mathrm{~m}^{2}$ glass ceiling. The glass slab is supported above by a cross-shaped bridge serving as a representative pavement for the bishop, and its night lighting's cross-form also refers to the Christian symbol [4]. Since the opening of the Visitor Center it has been of enormous importance in the life of the city: a worthy part of this World Heritage area. It deserves the restoration work, and the people's love and care. This is precisely what the following concept is intended to do.

\section{Special Kiosk}

The more than hundred-year-old building is a popular place of entertainment in 'Sétatér' square. The people of today are not concerned with what kind of troubled fate the building has. The original plan, by Gyula Piacsek in 1895, exceeded the predicted cost, and also in its dimensions proved to be excessive, so the final plans of the constructed building were finished by János Rauch and Sándor Kaufer. The construction based on the plans made for the Millennium lasted till 


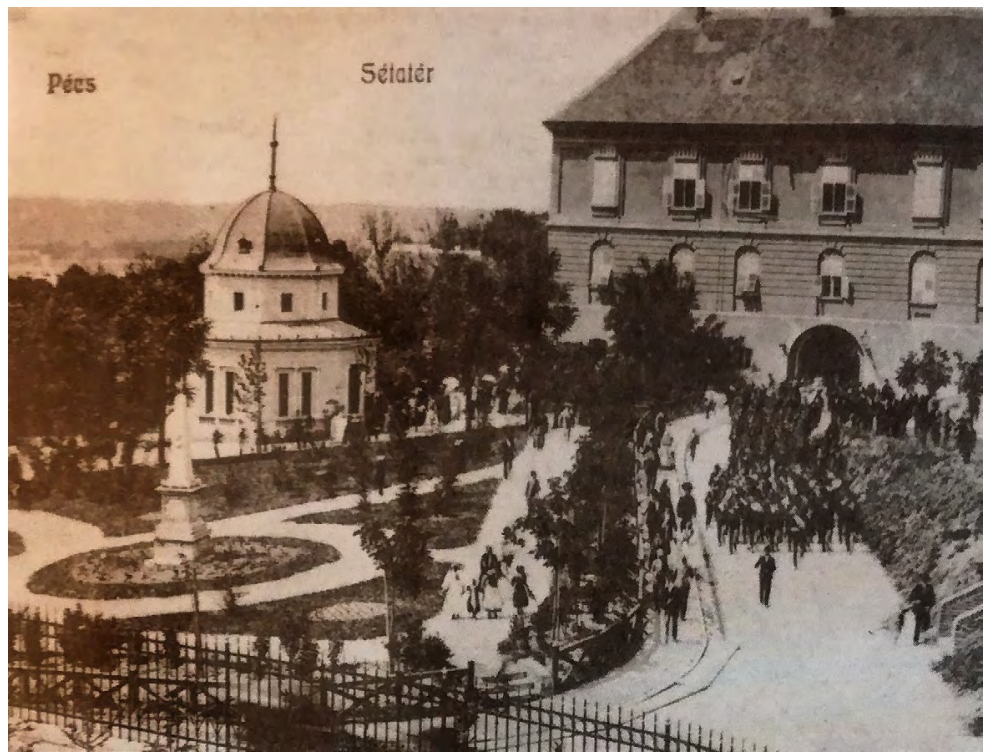

Figure 1. Pécs, Sétatér with kiosk at the turn of the century [5]

the summer of 1896, and the press was not enthusiastic about it. Perhaps Gyula Piacsek should also accept part of the criticism, since the original plan, with its higher cost was closer to a Renaissance creation and also to the capital's paragon: the Kiosk building in the Erzsébet square. The life of the hard created building was not a lucky one.

Yet we thought, through the design process, that to save and to keep it would be a productive and beneficial solution for everyone.

Because of its location, the building is the focus of life in the Visitor Center. Even 2006's development has taken into consideration the enhancement of the main entrance of Cella Septichora through the Kiosk, which will be explained later [5].

\section{The creation of the concept}

Through the design process we had to address the many needs of the customer. There is no proper sanitary block that could serve both employees and visitors. There is too little space connected to the ticket office, so there is not enough room for devices (printer, computer etc.), for the wardrobe and for the museum shop. In the Visitor Center there is only one main presentation area in the center of Cella Septichora, so there is no other room for presentation, education or exhibition. In the tourist season, which runs from early spring till late autumn, many visitors arrive in the city. To visit the World Heritage Area is part of every organized sightseeing program in the city. One of the main reasons of the development is to increase the number of visitors in this area. The existing entrance is open directly to the promenade with a "pipe" gesture which is perfectly suitable for the mood transition from outdoor to indoor space. However, it does not give possibilities for proper foreground neither outside nor inside, which would be really important because most of the visitors arrive as part of tourist groups. So it is a frequent occurrence that one or two buses stop at the same time which means $50-100$ visitors at the Center's entrance. That could seriously restrict the traffic of the promenade and results also in an inconvenient situation for the visitors. Therefore, the entrance situation must be developed and redesigned to fit all the needs of the intended function, at the same time keeping the spirituality of the place. As the part of the design concept the Visitor Center expanded with two education and exhibition rooms in the south side of Cella Septichora, and under the existing-remaining Kiosk building. We have made it possible to visit two further discovered tomb chambers in the east side (VIII. and IX. crypt), which it will be possible to walk around and they get also glass slab for closing the space above. To plan the proper presentation of the two new chambers gives us difficulties through the design process, because there were different data sources that indicated different locations for them. Neither of the documents could give us accurate information about 


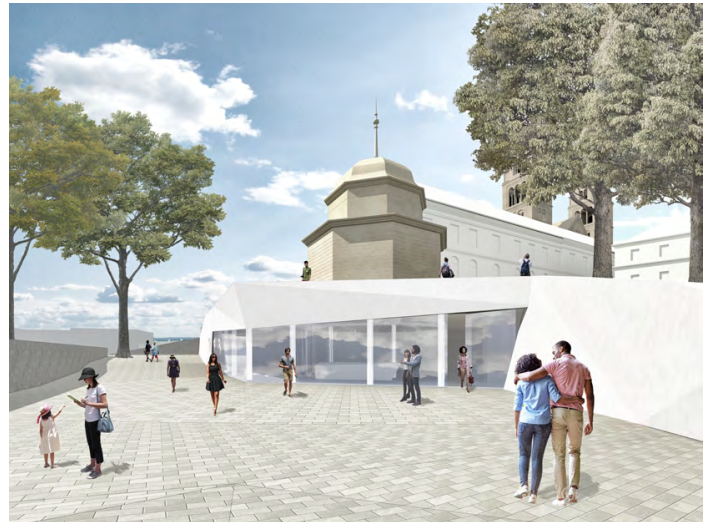

Figure 2. Pécs, Cella Septichora concept

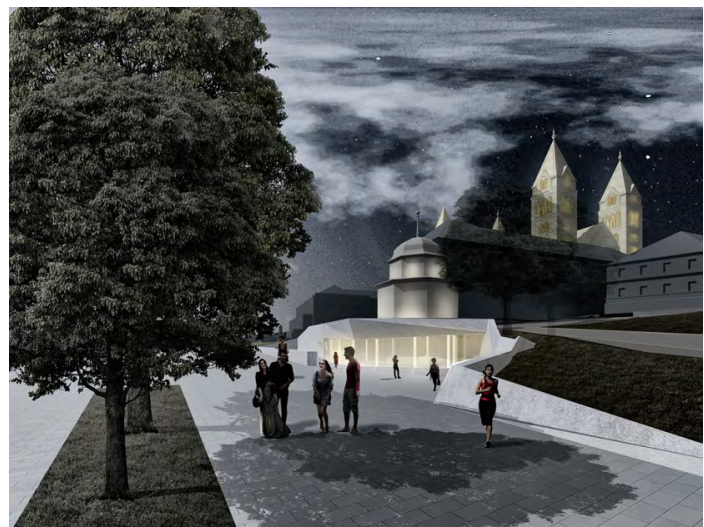

Figure 3. Pécs, Cella Septichora concept

the locations. Therefore it will be necessary for sure through the construction process to adapt the construction plans (and perhaps the design concept also) after the excavation of the artefacts. This however gives an unpredictable aspect to the construction process.

We designed the new entrance situation to create a square large enough to fit the needs of a proper space for one or two tourist group arriving. To choose the location of the new entrance it was a main viewpoint to keep the transition from lightened space to dark and lightened again. Because of that, the location of the main entrance corridor was chosen in the east side of the Kiosk. Visitors arrive in a side-lightened area, than they will go through a darker corridor to the Cella Septichora central room that is lightened from above. It gives the symbol from human world to divine. To make the Kiosk involved in the Center was discarded from the start, because the building is in private ownership and we could not count with it in the design. The great glass portal established in

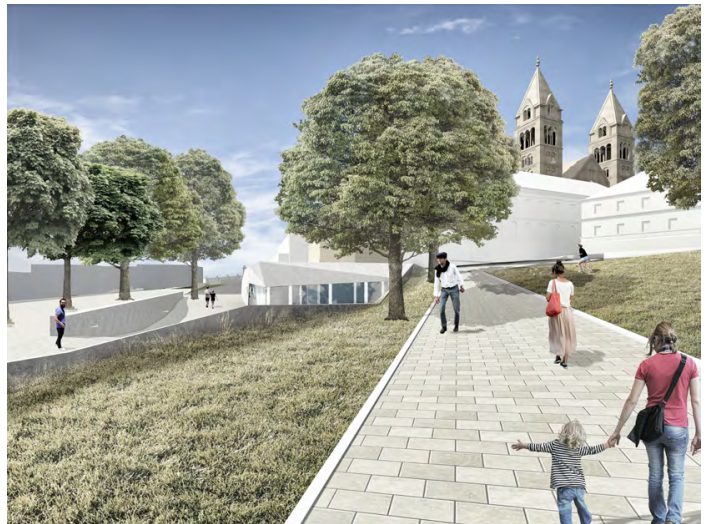

Figure 4. Pécs, Cella Septichora concept

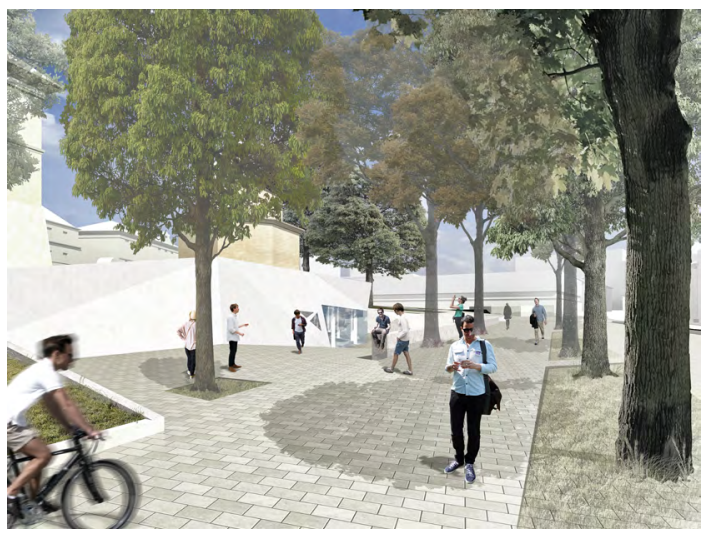

Figure 5. Pécs, Cella Septichora concept

the façade supports the whole entrance area and also the new museum shop with enough natural light. It was one of the deficiencies of the existing Center. Also the location of the ticket office and information desk was inappropriate.

\section{Conclusions}

This is a real complex design task which is perfectly able to present the connection between today's historical preservation and the contemporary design thinking. It would simplify and accelerate the design process if there would be a gathered accurate 3D documentation about the already revealed artefacts and the protective buildings around them. The amount and quality of the data supply made our work hard. Our plan is to create a precise 3D documentation that would support the future development and maintenance. With the help of a so called 'BIM' (Building Information Modelling) model we give an accurate information storage for the future 
designers, archaeologists and the building management. Also the digital stock of the historical preservation would develop.

Our goal is that the final concept fits with the life of the city, and satisfies the needs that were born since the completion of the original Center. It would also help the correct handling of the World Heritage Areas if the 'settlement decree' would deal with these areas separately, and the protective buildings and the artefacts within would get their own zone.

\section{References}

[1] Szigeti R.: A pécsi világörökségi negyed rehabilitációja és a BIM kapcsolata. In: PEME XIV. PhD. - Konferencia (Eds. Koncz I., Szova I.) Edited by Professzorok az Európai Magyarországért Egyesület, Budapest, 2017, 146-151.

[2] Pozsárkó Cs., Tóth Zs.: Pécs a római korban Vezető a pécsi világörökség helyszíneihez. Zsolnay Örökségkezelő Nonprofit Kft., Pécs, 2011, 6-9. ISBN: 978-963-89319-0-0.

[3] Bozóky A.: Világörökségi helyszínek - Pécs. Múltunk tükre, jövőnk gyökere. Kiadja a Zsolnay Örökségkezelő Nonprofit Kft., Pécs, 2013, 1-23.

[4] Mendöl Zs.: A sétatéri kioszk. Kaufer Sándor építész (1863-1900) müködése Pécs város mérnöki hivatalában. In: A Janus Pannonius Múzeum Évkönyve. 43 (1998) Janus Pannonius Múzeum, Pécs, 1999, 301-317.

[5] Bachman Z., Vince kiadó, Pécs, 2010, 107-145. ISBN: 978-963-303-001-1. 